\title{
New and interesting records of Lepidoptera from the Kola Peninsula, Northwestern Russia, in 2000-2009
}

\author{
Mikhail V. Kozlov \& Jaakko Kullberg
}

Kozlov, M. V. \& Kullberg, J. 2010: New and interesting records of Lepidoptera from the Kola Peninsula, Northwestern Russia, in 2000-2009. - Entomol. Fennica 21: 254-272.

Extensive sampling during 2000-2009 resulted in discovery of 65 species of Lepidoptera that have not been reported from the Kola Peninsula (i.e., Murmanskaya oblast of Russia) in our earlier publications. Critical revision of data published in several papers by the Russian scientists and in the comprehensive Catalogue of the Lepidoptera of Russia added further 59 species to the regional fauna (among which we controlled records of 15 species), while 60 species are excluded as erroneous or doubtful records. We also confirmed records of 12 species which were known from old publications only, and reported interesting findings of 71 rare species that expand their distribution range or demonstrate interesting ecological patterns. The fauna of moths and butterflies of the Murmansk region now totals 813 species.

M. V. Kozlov, Section of Ecology, University of Turku, FI-20014 Turku, Finland; E-mail:mikoz@utu.fi

J. Kullberg, Zoological Museum, University of Helsinki, P.O. Box 17, FI-00014 Helsinki, Finland; E-mail: jaakko.kullberg@helsinki.fi

Received 27 February 2010, accepted 3 June 2010

\section{Introduction}

The first regional checklist of moths and butterflies of the Kola Peninsula (Kozlov \& Jalava 1994) included 585 species, one of which (Coleophora betulaenanae Klimesch) is now considered the junior synonym of another $(C$. vacciniella). Additions reported in our earlier papers (Kozlov et al. 2000, Kozlov \& Kullberg 2006, 2008 ) increased this regional fauna to 690 species. Sampling of moths and butterflies around the towns of Apatity, Monchegorsk and Nikel, the use of light traps in several localities, and collecting trips to remote areas of the Kola Peninsula substantially expanded our knowledge on the regional fauna, justifying the need to summarize the records made during the past decade.
Since completion of the previous addition to the regional checklist (Kozlov et al. 2000) several Russian scientists published information on moths and butterflies of the Murmansk region (Mozolevskaya 1999, Shutova et al. 1999, Gorbunov 2001, Sviridov \& Shutova 2002, Shutova 2004, 2008, Makarova 2005, Kataev \& Berlina 2006, Mitina \& Kuznetsova 2006, Sviridov et al . 2006, Lvovsky \& Morgun 2007). Finally, the catalogue of moths and butterflies of Russia (Sinev 2008; note that although for the sake of brevity we refer to the entire Catalogue, the primary responsibility for the correctness of the information is hold by the authors of each specific part of it) included records of 51 species (six of which are labelled as questionable) that have not been reported for Murmansk region in our earlier publi- 
cations. Most of these publications are hard to access for researchers outside Russia; furthermore, some of the published data should be used with caution. Therefore we critically revise these publications and provide either supporting information or justification for excluding the records from the regional species list.

\section{Material and methods}

The paper is based on the examination of nearly 22,000 specimens, of which about 4,600 were pinned. The materials are mostly deposited in the Zoological Museum, University of Helsinki $(\mathrm{MZH})$. Some specimens of Geometridae were donated to the Zoological Museum in St. Petersburg (ZIN), and samples of 2009 were partially donated to the Natural History Museum (NHM) in London.

We continue to use numeric codes for the localities (Table 1) as in our earlier papers (Kozlov \& Jalava 1994, Kozlov et al. 2000, Kozlov \& Kullberg 2006, 2008), adding new localities to the end of the list (numbers 109-126). The UTM grid for the Kola Peninsula and a map showing sampling localities 1 to 79 was published by Kozlov \& Jalava (1994). Biogeographical provinces of Finland are given in italics; for a map of the provinces, consult Kullberg et al. (2002).

In the following list, an asterisk (*) denotes species that have not yet been recorded from the Kola Peninsula. A degree sign $\left(^{\circ}\right)$ indicates species that have been reported by the Russian researchers but were not mentioned in our earlier papers (Kozlov \& Jalava 1994, Kozlov et al. 2000, Kozlov \& Kullberg 2006, 2008). An exclamation mark (!) indicates records that confirm the occurrence of species that have been included in our first list (Kozlov \& Jalava 1994) on the basis of earlier publications only. Records of other species (mostly so-called "micros") are reported only when they confirm very old records of rare species or indicate interesting ecological patterns, such as mass occurrence of formerly uncommon species, or gradual spreading of species towards the north.

\section{List of species}

\section{Micropterigidae}

Micropterix mansuetella Z. 118: 2 exx. 10.7. 2009. Was known only from 43-29 (Kozlov \& Jalava 1994).

\section{Hepialidae}

Hepialus ganna (Hb.). 46 (road to Raswumchorr, 600 m a.s.1.): 1 ex. 11.8.2004. All previous records (Kozlov \& Jalava 1994) were more than 50 years old.

\section{Nepticulidae}

- Stigmella confusella (Wood \& Wlsm.). 38-11, 38-1, 43-14, 43-29, 84 (Shutova et al. 1999): mines on birch.

'Stigmella luteella (Stt.). 38-11: 1 mine on birch 26.8.2009; 61 (Shutova 2008).

Stigmella salicis (Stt.). 43-29: 1 ex. 4.7.2000; 56: 1 ex. 11.7.2000; 109-40: 1 ex. 30.6.2003. Was known from 39 and 61 (Kozlov \& Jalava 1994); the finding in 109-40 extends the distribution limit some $100 \mathrm{~km}$ towards north.

Ectoedemia weaveri (Stt.). 44, 55, 56: over 50 exx. collected by light traps (LT hereafter) during 1999-2001.

Ectoedemia minimella (Zett.). 38-15, 38-11, 381, 43-7, 43-9, 43-14, 43-20, 43-29, 43-35, 55. This species, earlier known only from 26 (Kozlov et al. 2000), appeared widely distributed in central part of the Kola Peninsula. Its density was especially high in 2009, when numerous mines were observed on Betula pubescens in most of study sites between 3815 and 43-35.

\section{Adelidae}

Adela cuprella (Den. \& Schiff.). 39-15: 1 ex. 21.6.2004; 43-20: 1 ex. 11.6.2001, feeding on inflorescence of Salix borealis at approx. 7 pm.

\section{Incurvariidae}

Incurvaria pectinea Hw. 43-35: 1 ex. 21.6.2008. Was known from 37 and 55 (Kozlov \& Jalava 1994).

\section{Prodoxidae}

${ }^{\circ}$ Lampronia capitella (Cl.). 60 (Shutova 2008).

${ }^{\circ}$ Lampronia corticella (L.). 126: 1 ex. 4.7.2003 (Sinev 2008).

\section{Tineidae}

'Infurcitinea ignicomella (H.-S.). 44: 3 exx. 24.26.7.1977 (Sinev 2008, and pers. comm.), 1 
Table 1. The collecting localities mentioned in the text.*

\begin{tabular}{lll}
\hline No $\quad$ Locality name & Latitude & Longitude \\
& $(\mathrm{N})$ & $(\mathrm{E})$
\end{tabular}

\begin{tabular}{lll}
\hline No Locality name & Latitude & Longitude \\
& $(\mathrm{N})$ & $(\mathrm{E})$
\end{tabular}

\begin{tabular}{|c|c|c|c|c|c|c|c|}
\hline 9 & Salmijärvi & $69^{\circ} 27^{\prime}$ & $30^{\circ} 08^{\prime}$ & 68 & Turij, 20 km E Umba & $66^{\circ} 33^{\prime}$ & $34^{\circ} 35^{\prime}$ \\
\hline 10 & Yläluostari & $69^{\circ} 25^{\prime}$ & $30^{\circ} 06^{\prime}$ & 70 & $45 \mathrm{~km} \mathrm{E} \mathrm{Umba}$ & $66^{\circ} 30^{\prime}$ & $35^{\circ} 10^{\prime}$ \\
\hline 11 & Zapolyarnyy & $69^{\circ} 26^{\prime}$ & $30^{\circ} 49^{\prime}$ & 71 & Olenitsa & $66^{\circ} 28^{\prime}$ & $35^{\circ} 20^{\prime}$ \\
\hline 12 & Petsamo & $69^{\circ} 33^{\prime}$ & $31^{\circ} 13^{\prime}$ & 73 & Kashkarantsy & $66^{\circ} 21^{\prime}$ & $36^{\circ} 00^{\prime}$ \\
\hline 17 & Pasvik (=Paatsjoki) & $69^{\circ} 20^{\prime}$ & $29^{\circ} 42^{\prime}$ & 74 & Varzuga & $66^{\circ} 24^{\prime}$ & $36^{\circ} 35^{\prime}$ \\
\hline 18 & Nautsi & $69^{\circ} 00^{\prime}$ & $29^{\circ} 03^{\prime}$ & 77 & Kuzomen & $66^{\circ} 18^{\prime}$ & $36^{\circ} 46^{\prime}$ \\
\hline 20 & Höyhenjärvi & $69^{\circ} 10^{\prime}$ & $29^{\circ} 18^{\prime}$ & 82 & Luvenga Archipelago & - & - \\
\hline 23 & Murmansk & $68^{\circ} 57^{\prime}$ & $33^{\circ} 05^{\prime}$ & 82-BV & Berezhnoy Vlasov Is. & $67^{\circ} 05^{\prime} 04^{\prime \prime}$ & $32^{\circ} 41^{\prime} 33^{\prime \prime}$ \\
\hline 27 & Köngäs & $68^{\circ} 35^{\prime}$ & $29^{\circ} 28^{\prime}$ & 83 & Northern Archipelago & - & - \\
\hline 28 & Lutto & - & - & 83-BL & Lomnishnyi Bolshoj Is. & $66^{\circ} 58^{\prime} 14^{\prime \prime}$ & $32^{\circ} 37^{\prime} 35^{\prime \prime}$ \\
\hline 34 & Voronja r. & - & - & 83-DE & Devichja Luda & $66^{\circ} 59^{\prime} 20^{\prime \prime}$ & $32^{\circ} 36^{\prime} 33^{\prime \prime}$ \\
\hline \multirow[t]{2}{*}{$38-1$} & Road St. Petersburg- & $67^{\circ} 56^{\prime} 04^{\prime \prime}$ & $32^{\circ} 49^{\prime} 08^{\prime \prime}$ & 83-RJ & Rjashkov Is. & $67^{\circ} 02^{\prime} 56^{\prime \prime}$ & $32^{\circ} 33^{\prime} 37^{\prime \prime}$ \\
\hline & Murmansk, $1 \mathrm{~km} \mathrm{~N}$ of 39 & & & 83-TS & Tsentralnaja Luda & $67^{\circ} 03^{\prime} 10^{\prime \prime}$ & $32^{\circ} 35^{\prime} 52^{\prime \prime}$ \\
\hline $38-3$ & id., $3 \mathrm{~km} \mathrm{~N}$ of 39 & $67^{\circ} 57^{\prime} 11^{\prime \prime}$ & $32^{\circ} 50^{\prime} 46^{\prime \prime}$ & 84 & Porya Guba & $66^{\circ} 48^{\prime}$ & $33^{\circ} 43^{\prime}$ \\
\hline $38-11$ & id., $11 \mathrm{~km} \mathrm{~N}$ of 39 & $68^{\circ} 00^{\prime} 59^{\prime \prime}$ & $32^{\circ} 57^{\prime} 03^{\prime \prime}$ & 84-GO & Gorelyi Is. & $66^{\circ} 25^{\prime} 48^{\prime \prime}$ & $33^{\circ} 46^{\prime} 27^{\prime \prime}$ \\
\hline $38-15$ & id., $15 \mathrm{~km} \mathrm{~N}$ of 39 & $68^{\circ} 02^{\prime} 20^{\prime \prime}$ & $33^{\circ} 00^{\prime} 53^{\prime \prime}$ & 85-VE & Velikyi Is. & $66^{\circ} 33^{\prime} 57^{\prime \prime}$ & $33^{\circ} 20^{\prime} 00^{\prime \prime}$ \\
\hline 39 & Monchegorsk & $67^{\circ} 56^{\prime}$ & $32^{\circ} 56^{\prime}$ & 89 & mouth of Makeevskij R. & $66^{\circ} 11^{\prime} 22^{\prime \prime}$ & $37^{\circ} 24^{\prime} 16^{\prime \prime}$ \\
\hline \multirow[t]{2}{*}{$43-5$} & Road St. Petersburg- & $67^{\circ} 52^{\prime} 59^{\prime \prime}$ & $32^{\circ} 46^{\prime} 40^{\prime \prime}$ & 91 & mouth of Rombach R. & $66^{\circ} 05^{\prime} 31^{\prime \prime}$ & $37^{\circ} 53^{\prime} 27^{\prime \prime}$ \\
\hline & Murmansk, $5 \mathrm{~km}$ S of 39 & & & 92 & $8 \mathrm{~km}$ W Tetrino & $66^{\circ} 04^{\prime} 56^{\prime \prime}$ & $38^{\circ} 03^{\prime} 38^{\prime \prime}$ \\
\hline $43-7$ & id., $7 \mathrm{~km} \mathrm{~S}$ of 39 & $67^{\circ} 51^{\prime} 58^{\prime \prime}$ & $32^{\circ} 47^{\prime} 50^{\prime \prime}$ & 93 & mouth of Kamenka R. & $66^{\circ} 03^{\prime} 47^{\prime \prime}$ & $38^{\circ} 19^{\prime} 54^{\prime \prime}$ \\
\hline $43-9$ & id., $9 \mathrm{~km} \mathrm{~S}$ of 39 & $67^{\circ} 51^{\prime} 01^{\prime \prime}$ & $32^{\circ} 48^{\prime} 10^{\prime \prime}$ & 95 & 2 km N Chapoma & $66^{\circ} 06^{\prime} 54^{\prime}$ & $38^{\circ} 51^{\prime} 18^{\prime \prime}$ \\
\hline $43-11$ & id., $11 \mathrm{~km} \mathrm{~S}$ of 39 & $67^{\circ} 49^{\prime} 44^{\prime \prime}$ & $32^{\circ} 46^{\prime} 59^{\prime \prime}$ & 100 & mouth of Pulonga R. & $66^{\circ} 15^{\prime} 57^{\prime \prime}$ & $39^{\circ} 58^{\prime} 17^{\prime \prime}$ \\
\hline $43-14$ & id., $14 \mathrm{~km} \mathrm{~S}$ of 39 & $67^{\circ} 48^{\prime} 03^{\prime \prime}$ & $32^{\circ} 46^{\prime} 56^{\prime \prime}$ & 103 & 50 km E Murmansk & $68^{\circ} 53^{\prime}$ & $34^{\circ} 24^{\prime}$ \\
\hline $43-20$ & id., $20 \mathrm{~km} \mathrm{~S}$ of 39 & $67^{\circ} 45^{\prime} 31^{\prime \prime}$ & $32^{\circ} 48^{\prime} 29^{\prime \prime}$ & 109 & Nikel & $69^{\circ} 25^{\prime}$ & $30^{\circ} 13^{\prime}$ \\
\hline $43-29$ & id., $29 \mathrm{~km} \mathrm{~S}$ of 39 & $67^{\circ} 40^{\prime} 39^{\prime \prime}$ & $32^{\circ} 49^{\prime} 27^{\prime \prime}$ & $109-3$ & 3 km S Nikel & $69^{\circ} 23^{\prime} 32^{\prime \prime}$ & $30^{\circ} 10^{\prime} 45^{\prime \prime}$ \\
\hline $43-35$ & id., $35 \mathrm{~km} \mathrm{~S}$ of 39 & $67^{\circ} 38^{\prime} 21^{\prime \prime}$ & $32^{\circ} 45^{\prime} 00^{\prime \prime}$ & $109-10$ & 10 km S Nikel & $69^{\circ} 21^{\prime} 15^{\prime \prime}$ & $30^{\circ} 03^{\prime} 11^{\prime \prime}$ \\
\hline $43-41$ & id., $41 \mathrm{~km} \mathrm{~S}$ of 39 & $67^{\circ} 34^{\prime} 38^{\prime \prime}$ & $32^{\circ} 32^{\prime} 54^{\prime \prime}$ & $109-20$ & 20 km S Nikel & $69^{\circ} 16^{\prime} 14^{\prime \prime}$ & $30^{\circ} 04^{\prime} 56^{\prime \prime}$ \\
\hline $43-47$ & id., $47 \mathrm{~km} \mathrm{~S}$ of 39 & $67^{\circ} 34^{\prime} 46^{\prime \prime}$ & $33^{\circ} 35^{\prime} 22^{\prime \prime}$ & $109-40$ & 40 km S Nikel & $69^{\circ} 04^{\prime} 28^{\prime \prime}$ & $30^{\circ} 12^{\prime} 15^{\prime \prime}$ \\
\hline 44 & Tshunosero & $67^{\circ} 39^{\prime} 06^{\prime \prime}$ & $32^{\circ} 38^{\prime} 51^{\prime \prime}$ & $110-4$ & 4 km NE Zapolyarnyy & $69^{\circ} 25^{\prime} 30^{\prime \prime}$ & $30^{\circ} 52^{\prime} 45^{\prime \prime}$ \\
\hline $44 a$ & Tshuna-tundra mts. & - & - & $110-10$ & 10 km NE Zapolyarnyy & $69^{\circ} 26^{\prime} 50^{\prime \prime}$ & $31^{\circ} 02^{\prime} 10^{\prime \prime}$ \\
\hline 45 & Jokostrov (Ekostroff) & $67^{\circ} 33^{\prime} 52^{\prime \prime}$ & $33^{\circ} 04^{\prime} 26^{\prime \prime}$ & $110-40$ & 40 km E Zapolyarnyy & $69^{\circ} 26^{\prime} 34^{\prime \prime}$ & $31^{\circ} 56^{\prime} 42^{\prime \prime}$ \\
\hline 46 & Khibiny mt. (Hiipinä) & - & - & 111 & $4 \mathrm{~km} \mathrm{E}$ of Ura-Guba & $69^{\circ} 17^{\prime}$ & $32^{\circ} 53^{\prime}$ \\
\hline 47 & Revda & $67^{\circ} 57^{\prime}$ & $34^{\circ} 34^{\prime}$ & 112 & Sem Ostrovov & - & - \\
\hline 55 & Apatity & $67^{\circ} 35^{\prime}$ & $32^{\circ} 23^{\prime}$ & 113 & 45 km W Lovozero & $68^{\circ} 05^{\prime}$ & $34^{\circ} 08^{\prime}$ \\
\hline 56 & Kirovsk & $67^{\circ} 38^{\prime}$ & $33^{\circ} 42^{\prime}$ & 114 & Azimouth River & $67^{\circ} 50^{\prime} 29^{\prime \prime}$ & $34^{\circ} 22^{\prime} 21^{\prime \prime}$ \\
\hline $56 a$ & 15 km E Kirovsk & $67^{\circ} 32^{\prime} 16^{\prime \prime}$ & $33^{\circ} 57^{\prime} 52^{\prime \prime}$ & 115 & Khibiny (railway station) & $67^{\circ} 40^{\prime} 20^{\prime \prime}$ & $33^{\circ} 14^{\prime} 58^{\prime \prime}$ \\
\hline $58 a$ & Vuorijarvi & $66^{\circ} 47^{\prime}$ & $30^{\circ} 08^{\prime}$ & 116 & Nizhnij Tsagjavr & $67^{\circ} 34^{\prime}$ & $35^{\circ} 08^{\prime}$ \\
\hline 59 & Alakurtti & $66^{\circ} 58^{\prime}$ & $30^{\circ} 21^{\prime}$ & 117 & Inga (abandoned) & $67^{\circ} 09^{\prime} 33^{\prime \prime}$ & $34^{\circ} 21^{\prime} 52^{\prime \prime}$ \\
\hline $59 a$ & 35 km W Kandalaksha & $67^{\circ} 06^{\prime}$ & $31^{\circ} 37^{\prime}$ & 118 & Muna (abandoned) & $67^{\circ} 05^{\prime} 29^{\prime \prime}$ & $34^{\circ} 26^{\prime} 28^{\prime \prime}$ \\
\hline 60 & Kandalaksha & $67^{\circ} 10^{\prime}$ & $32^{\circ} 25^{\prime}$ & 119 & Vostochnoe Munozero & $67^{\circ} 01^{\prime} 13^{\prime \prime}$ & $34^{\circ} 47^{\prime} 48^{\prime \prime}$ \\
\hline 61 & Luvenga & $67^{\circ} 07^{\prime}$ & $32^{\circ} 42^{\prime}$ & 120 & Rouksa River & $67^{\circ} 00^{\prime} 48^{\prime \prime}$ & $35^{\circ} 11^{\prime} 01^{\prime \prime}$ \\
\hline 62 & Knyazhaya Guba & $66^{\circ} 49^{\prime}$ & $32^{\circ} 21^{\prime}$ & 121 & 110 km SE Apatity & $66^{\circ} 59^{\prime} 13^{\prime \prime}$ & $35^{\circ} 24^{\prime} 34^{\prime \prime}$ \\
\hline 64 & Kanosero & $67^{\circ} 02^{\prime}$ & $34^{\circ} 04^{\prime}$ & 122 & Indel & $66^{\circ} 57^{\prime} 49^{\prime \prime}$ & $35^{\circ} 16^{\prime} 49^{\prime \prime}$ \\
\hline $64 a$ & Kolvitsa & $67^{\circ} 05^{\prime}$ & $33^{\circ} 00^{\prime}$ & 123 & Tominga tributary & $67^{\circ} 04^{\prime} 14^{\prime \prime}$ & $35^{\circ} 20^{\prime} 20^{\prime \prime}$ \\
\hline 65 & Ponoi & $67^{\circ} 05^{\prime}$ & $41^{\circ} 07^{\prime}$ & 124 & 25 km E Kandalaksha & $67^{\circ} 07^{\prime}$ & $32^{\circ} 54^{\prime}$ \\
\hline 66 & Kovda (Kouta) & $66^{\circ} 41^{\prime}$ & $32^{\circ} 52^{\prime}$ & 125 & Salnitsa & $66^{\circ} 22^{\prime} 35^{\prime \prime}$ & $35^{\circ} 41^{\prime} 28^{\prime \prime}$ \\
\hline 67 & Umba & $66^{\circ} 42^{\prime}$ & $34^{\circ} 19^{\prime}$ & 126 & Lodochnyi & $66^{\circ} 17^{\prime} 35^{\prime \prime}$ & $36^{\circ} 24^{\prime} 48^{\prime \prime}$ \\
\hline
\end{tabular}

*Geographical co-ordinates were rounded off to minutes when the sampled area exceeded $1 \mathrm{~km}^{2}$ or when the extent of the historical sampling area cannot be recovered. Co-ordinates are not provided when the locality name refers to an area exceeding $100 \mathrm{~km}^{2}$. 
ex. 21.6.2000, 6 exx. 19.-27.7.2001 (LT).

*Nemapogon variatellus (Clem.). 43-5: 1 ex. 14.7.2004. The northernmost records in Finland from $\mathrm{Kb}$ and $\mathrm{Om}$ (Kullberg et al. 2010).

Nemapogon picarellus (C1.). 56: 1 ex. 16.7.2001

(LT). Was known only from the north-western part of the Murmansk region (Kozlov \& Jalava 1994).

*Tinea steueri Petersen. 55: 1 ex. 27.6.2006. The northernmost records in Finland from $\mathrm{Oa}$ and Kb (Kullberg et al. 2010).

${ }^{\circ}$ Tinea trinotella Thnbg. 83-RJ (Shutova et al. 1999).

Niditinea striolella (Matsum.). 55: 1 ex. 27.6. 2006; 74: 1 ex. 19.7.2007. Was known only from 38-11 (Kozlov et al. 2000).

${ }^{\circ}$ Niditinea fuscella (L.). 61 (Shutova et al. 1999); we have examined the photography of this specimen.

\section{Psychidae}

Taleporia borealis (Wck.). 109-40: 1 ex. 30.6. 2003; 121: 1 ex. 10.-12.7.2009. Was known from 12, 34 (Valle 1933), and 44a (Kozlov et al. 2000).

*Sideria rupicolella (Sauter). 45: 1 ex. 26.6.1999 (LT). The northernmost records in Finland from Lkor and $\mathrm{Li}$ (Kullberg et al. 2010).

\section{Roesslerstammiidae}

Roesslerstammia erxlebella (F.). 56a: 1 ex. 27.6. 2004; 61 (Shutova 2008). Was known only from 55 (Kozlov \& Jalava 1994).

\section{Bucculatricidae}

Bucculatrix cristatella Z. 43-5: 1 ex. 14.7.2004; 44: 1 ex. 21.6.2000. Was known from 56, 60 (Kozlov \& Jalava 1994) and 61 (Shutova 2004; as Bucculatrix cydoniella Hbn.).

\section{Gracillariidae}

${ }^{\circ}$ Caloptilia suberinella (Tengstr.). 43-29: 1 ex. 22.6.2000, 2 exx. 22.7.2006 (ex 1. on birch); 61 (Shutova 2004).

Caloptilia elongella (L.). 55: 4 exx. 18.9.2.10.2000 (LT). The northernmost record; was known only from 84-GO (Kozlov et al. 2000).

!Caloptilia stigmatella (F.). 55: 1 ex. 19.7.2001 (LT). Was reported from 28 (Krogerus 1943).

${ }^{\circ}$ Gracillaria syringella (F.). 55: numerous mines on Syringa josikaea in late July of 2010. Was reported from 23 (Mitina \& Kuznetsova 2006).

\section{Yponomeutidae}

* Kessleria fasciapennella (Stt.). 73: 1 ex. 7.6. 2003. The northernmost records in Finland from $L e$ and $L i$ (Kullberg et al. 2010).

Argyresthia abdominalis Z. 55: 1 ex. 21.7.1999 (LT). Was known only from 44 (Kozlov \& Jalava 1994).

'Argyresthia aurulentella Stt. 61 (Shutova et al. 1999).

*Argyresthia brockeella (Hb.). 74: 1 ex. 3.8.2005 (LT). The northernmost records in Finland from $O b a$ and $O b b$ (Kullberg et al. 2010).

\section{Ypsolophidae}

Ypsolopha parenthesella (L.). 38-1, 43-7, 43-9, 43-29, 43-35, 44, 55, 56, 74: over 90 exx. collected during 2000-2008. This species was earlier (1994-1998) known only from 61 (Shutova et al. 1999, Kozlov et al. 2000). Since then, it expanded to the central part of the Kola Peninsula where attained high densities, causing substantial damage of mountain birch around Monchegorsk in 2006.

\section{Lyonetiidae}

!Lyonetia ledi Wck. 56: 1 ex. 29.8.2000 (LT). Was reported from 28 (Krogerus 1943) and 85-VE (Shutova 2004).

\section{Elachistidae}

*Agonopterix conterminella (Z.). 56: 1 ex. 9.8.2000 (LT). The northernmost record in Finland from Lkoc (Kullberg et al. 2010).

*Agonopterix angelicella (Hb.). 74: 1 ex. 8.9.2006 (LT). The northernmost records in Finland from $O b a$ and $O b b$ (Kullberg et al. 2010). Agonopterix broennoeensis (Strand). 44: 1 ex. 16.9.2001 (LT); 45: 2 exx. 14.-23.8.1999 (LT); 55: 1 ex. 18.8.1999, 2 exx. 29.8.-8.9. 2000 (LT), 3 exx. 16.-27.8.2001 (LT); 61 (Shutova 2008). Was known only from 46 (Kozlov \& Jalava 1994). This species is very similar to A. kaekeritziana, and has been sometimes confused with it (see below).

'Agonopterix kaekeritziana (L.). 61 (Shutova 2008); we have examined a photograph of this specimen; the identification was confirmed by A. Lvovsky (pers. comm.). Earlier records by Lvovsky (1988) and Sinev (2008) were based on the specimen from 46 that was identified by J. Jalava as A. broennoeensis (A. Lvovsky, pers. comm.), cited above.

Elachista diederichsiella E. Hering. 61 (Shutova 
2004); 111 (grassland along the Barents Sea shore): 3 exx. 16.7.2006. Was known only from 77 (Kozlov \& Jalava 1994).

Elachista nobilella Z. 43-29: 1 ex. 28.6.1999; 44:

1 ex. 10.7.2000 (LT); 45: 1 ex. 10.7.1999(LT);

55: 4 exx. 7.-14.7.1999, 1 ex. 10.7.2000 (LT);

70: 1 ex. 29.6.2000. Was known only from 4314 (Kozlov \& Jalava 1994).

${ }^{\circ}$ Elachista pomerana Frey. 61 (Shutova 2004, Sinev 2008).

${ }^{\circ}$ Chrysoclista lathamella T. Fletcher. 43-7: 1 ex.

9.7.2002 (Sinev 2008).

\section{Oecophoridae}

*Denisia obscurella (Brandt). 110-10: 1 ex. 29.6.2003. The northernmost record in Finland from $L i$ (Kullberg et al. 2010).

\section{Momphidae}

Mompha sturnipennella (Tr.). 38-1: 1 ex. 9.7. 2003, 1 ex. 24.6.2004, 1 ex. 14.7.2004, 1 ex. 23.6.2005, 4 exx. 8.7.2006. Moths were disturbed at day time from fireweed, Chamaenerion angustifolium (L.) Holub, densely growing in heavily polluted industrial barren. Was known from 60 (Shutova 2004, as $M$. nodicolella Fuchs) and 93 (Kozlov \& Kullberg 2006).

\section{Coleophoridae}

*Coleophora alnifoliae Barasch. 74: 1 ex. 26.63.7.2004 (LT); 116: 1 ex. 9.7.2006. The northernmost record in Finland from $\mathrm{Oba}$ (Kullberg et al. 2010).

*Coleophora plumbella Kanerva. 118: 1 ex. 10.7.2009. Found in all provinces of northern Finland (Kullberg et al. 2010).

!Coleophora vitisella Gregson. 109-3: 1 ex. 4.7. 2007; 109-10: 1 ex. 4.7.2007. Was recorded from 17 (Valle 1933) and 27 (Krogerus 1943).

Coleophora thulea Johansson. 116: 2 exx. 9.7.2006; 120: 1 ex. 10.7.2009. Was known from 34, 61 and 103 (Kozlov \& Jalava 1994, Kozlov \& Kullberg 2008).

${ }^{\circ}$ Coleophora deauratella Lienig \& Z. 61 (Shutova et al. 1999); 118: 1 ex. 10.7.2009.

*Coleophora albidella (Den. \& Schiff.). 110-40: 1 ex. 6.2006, larval case on Salix sp. Found in all provinces of Finland (Kullberg et al. 2010).

Coleophora antennariella (H.-S.). 43-35: 1 ex. 8.7.2006. Was known only from 59a (Kozlov \& Jalava 1994).

Coleophora otidipennella (Hb.). 46: 1 ex.
21.8.2006 (V. Anikin, pers. comm). The northernmost record; was known only from 58a (Kozlov \& Jalava 1994).

${ }^{\circ}$ Coleophora sternipennella (Zett.). 61, 83-TS (Shutova et al. 1999).

Coleophora atriplicis Meyr. 61: 1 ex. 21.6.2003; 68: 1 ex. 25.6.2003. Was known from 60 (collected in 1870) and 93 (Kozlov \& Jalava 1994, Kozlov \& Kullberg 2006). The species is common on the littoral of the White Sea, as indicated by sampling at Chupa and Kartesh Island in Northern Karelia (A. Przhiboro, pers. comm.).

Coleophora pappiferella Hofm. 77: 1 ex. 23.6.1999; 125: 4 exx. 22.6.1999. Was known from 28 and 55 (Kozlov \& Jalava 1994).

Coleophora trochilella (Dup.). 44: 1 ex. 10.7.2001 (LT). Was known from 55 and 100 (Kozlov \& Jalava 1994, Kozlov \& Kullberg 2006).

Coleophora paripennella Z. 55: 1 ex. 7.7.2001 (LT); 109: 1 ex. 30.6.2003. A single specimen was collected from 10 in 1938 (Kozlov \& Jalava 1994).

${ }^{\circ}$ Coleophora alcyonipennella (Koll.). 61 (Shutova et al. 1999); 122: 3 exx. 11.7.2009.

\section{Gelechiidae}

Bryotropha similis (Stt.). 45: 1 ex. 26.6.1999 (LT); 55: 1 ex. 30.6.2000 (LT); 68: 1 ex. 28.6. 2000. Was known from 61 and 70 (Kozlov \& Jalava 1994).

Aroga velocella (Z.). 55: 1 ex. 16.8.2001 (LT). Was known from 60 and 67 (Kozlov \& Jalava 1994).

*Filatima incomptella (H.-S.). 43-29: 1 ex. 14.7.2004; 68: 1 ex. 27.6.2002; 109-20: 1 ex. 7.7.2004. The northernmost records in Finland from $L e$ and $L i$ (Kullberg et al. 2010).

${ }^{\circ}$ Gnorimoschema herbichii (Nowicki). 43-35: 1 ex. 24.6.2004. Reported for the Murmansk region (Sinev 2008) after Povolný (2002); we were unable to identify the primary source for this record.

Gnorimoschema epithymellum (Stgr.). 55: 2 exx. 6.8.2001 (LT); 74: 1 ex. 27.7.2004 (LT). Was known from 61 (Shutova et al. 1999) and 93 (Kozlov \& Kullberg 2006).

Scrobipalpa atriplicella (F. v. R.). 68: 3 exx. 28.6.2000. Was known from 77 (Kozlov \& 
Jalava 1994), 93 and 100 (Kozlov \& Kullberg 2006).

*Scrobipalpa samadensis (Pfaff.). 68: 1 ex. 28.6.2000. A coastal species living on Plantago maritima; the northernmost record in Finland from Oba (Kullberg et al. 2010). Also found in Northern Karelia (Nilmoguba, 2 exx. 14.7.2000).

${ }^{\circ}$ Caryocolum pullatellum (Tngstr.). 61 (Shutova et al. 1999); 74: 2 exx. 27.7.-15.8.2004 (LT).

*Caryocolum blandelloides Karsholt. 61: 1 ex. 18.8.2005. The specimen was reported by Shutova (2008) as C. blandellum (Dougl.); our identification is based on a photograph of the male genitalia. The species inhabits dry meadows; it is considered endangered and probably overlooked in Finland where it is known from three localities in the provinces $A l, A b$, and $N$ (Kullberg et al. 2010). The foodplant is Cerastium semidecandrum, possibly also $C$. fontanum.

Syncopacma karvoneni (Hackman). 34: 1 ex. 1.7.2006; 45: 1 ex. 10.7.1999 (LT); 55: 3 exx. 7.7.1999 (LT). Was known from 61 and 68 (Kozlov \& Jalava 1994).

'Hypatima rhomboidella (L.). 61 (Shutova 2008).

!Neofaculta ericetella (Geyer). 68: 2 exx. 27.6.2002. Was reported from 28 (Krogerus 1943).

\section{Sesiidae}

Sesia bembeciformis (Hb.). 38-1: 1 ex. 10.7. 2002; 38-3: 1 ex. 23.7.1997; 43-5: 1 ex. 21.7. 1997, 1 ex. 8.7.2006; 43-9: 1 ex. 14.8.1996. These records confirm that this rare species, originally found in an industrial barren at 43-7 (Kozlov \& Jalava 1994), is relatively common across the severely polluted area near the nickel-copper smelter at Monchegorsk.

!Synanthedon spheciformis (Den. \& Schiff). 381: 1 ex. 6.7.2005, flying among willow bushes (Salix borealis, $S$. caprea) in an industrial barren. Was reported from 27 (Krogerus 1943).

Synanthedon polaris (Stgr.). 38-1: 1 ex. 6.7.2005, together with the previous species. Was known from 91 and 92 (Kozlov \& Kullberg 2006).

\section{Tortricidae}

Acleris comariana (Lienig \& Z.). 44: 5 exx. 29.8.-8.9.2000 (LT); 45: 1 ex. 20.8.2008, common among Menyanthes trifoliata in a small lake. Was known only from 56 (Kozlov \& Jalava 1994).

*Acleris effractana (Hb.). 55: 7 exx. 29.8.8.9.2000 (LT); 74: 1 ex. 8.-9.2006 (LT). This species had long been considered a synonym of A. emargana (F.), and its identity was revealed only recently (Karsholt et al. 2005). Earlier records of $A$. emargana from 55 and 61 (Kozlov et al. 2000) should be attributed to this species.

Acleris aspersana (Hb.). 44: 7 exx. 29.8.2000 (LT); 55: 8 exx. 19.8.2000 (LT); 56: 1 ex. 29.8. 2000 (LT); 84 (Shutova et al. 1999, as $A$. shepherdana). Was known only from 10 (Kozlov \& Jalava 1994).

*Acleris hastiana (L.). 74: 5 exx. 28.9.2004 (LT). The northernmost records in Finland from Lkoc and Lkor (Kullberg et al. 2010).

'Acleris notana (Don.). 44: 1 ex. 29.8.2000, 1 ex. 16.9.2001 (LT); 56: 1 ex. 29.8.2000 (LT). Reported for the Murmansk region by Sinev (2008); however, the source of information cannot be recovered (S. Sinev, pers. comm.).

-Acleris logiana (Cl.). 61 (Shutova 2008).

*Acleris lipsiana (Den. \& Schiff.). 43-29: 1 ex. 12.6.2002; 74: 1 ex. 28.9.2004 (LT). Recorded in all provinces of Finland (Kullberg et al. 2010).

${ }^{\circ}$ Phtheochroa inopiana (Hw.). 55: 1 ex. 16.8. 2001 (LT). Reported for the Murmansk region by Sinev (2008); however, the source of information cannot be recovered (S. Sinev, pers. comm.).

Aethes rutilana (Hb.). 55: 1 ex. 20.7.2000. Was known only from 70 (Kozlov \& Jalava 1994).

Exapate congelatella (Cl.). 55: 1 ex. Apatity 28.9.2000 (LT); 74: 1 ex. 28.9.2004 (LT). Was known only from 61 (Kozlov et al. 2000).

Eana penziana (Thnbg.). 44: 1 ex. 19.8.2000, 1 ex. 14.8.2001 (LT); 55: 1 ex. 4.8.1999, 1 ex. 29.8.2000 (LT). Was known from 61 (Shutova 2004) and 73 (Kozlov \& Jalava 1994).

Pandemis cerasana (Hb.). 38-1: 1 ex. 8.7.2006. Was known only from 61 (Kozlov \& Jalava 1994).

*Lobesia virulenta Bae \& Komai. 116: 1 ex. 9.7.2006. The northernmost records in Finland from $O b b$ and $K s$ (Kullberg et al. 2010).

${ }^{\circ}$ Hedya dimidiana (Cl.). Reported for the Murmansk region by Sinev (2008); however, the 
source of information cannot be recovered (S. Sinev, pers. comm.).

*Apotomis capreana (Hb.). 74: 1 ex. 8.-9.2006

(LT). The northernmost records in Finland from $O b a$ and $O b b$ (Kullberg et al. 2010).

Apotomis fraterculana Krog. 43-29: 1 ex. 25.6.2001; 110-4: 1 ex. 29.6.2003. The locality $110-4$ is only some $30 \mathrm{~km}$ east from 9 where one of the syntypes of this rarely sampled species had been collected.

Ancylis laetana (F.). 38-1, 43-5, 43-7, 43-9: 29 exx. The single specimen was collected from 67 in 1885 (Kozlov \& Jalava 1994); later found in 83-DE (Shutova et al. 1999) and 85VE (Shutova 2004). In 2001, a population was discovered in 38-1, in an aspen grove in an industrial barren near Monchegorsk. This locality was surveyed annually since 1993, thus the date of establishment can be reported with sufficient accuracy. During 2004-2006 it was also collected in barren localities 43-5, 43-7 and 43-9.

Ancylis diminutana (Hw.). 56: 1 ex. 7.7.2001 (LT); 109-40: 1 ex. 30.6.2003. Was known only from 100 (Kozlov \& Kullberg 2006).

*Ancylis paludana (Barret). 77 (sandy sea shore at the mouth of Varzuga River): 1 ex. 29.6.2004. In Finland known only from maritime localities in $\mathrm{Ab}, \mathrm{N}, \mathrm{Om}, \mathrm{Oba}$ and $\mathrm{Obb}$ (Kullberg et al. 2010), mostly associated with Lathyrus japonicus.

'Thiodia citrana (Hb.). Reported for the Murmansk region by Sinev (2008); however, the source of information cannot be recovered (S. Sinev, pers. comm.).

'Spilonota ocellana (Den. \& Schiff.). 46: 1 ex. 8.7.1934 (Sinev 2008, and pers. comm.). An unexpected record that was published by Kuznetsov (1978) but overlooked by Kozlov \& Jalava (1994); in Finland this aspen (Populus tremula) feeding species is confined to the southern provinces (Kullberg et al. 2010).

○Epinotia caprana (F.). 61 (Shutova 2004).

Epinotia solandriana (L.). 44: 2 exx. 8.18.9.2000 (LT); 56: 2 exx. 18.-29.8.2000 (LT). Was known only from 61 (Kozlov et al. 2000).

Epinotia brunnichana (L.). 38-1: 1 ex. 28.7.2005; 38-11: 1 ex. 21.8.2008. Was known only from 61 (Kozlov et al. 2000).

${ }^{\circ}$ Epinotia ramella (L.). 38-1: 1 ex. 31.7.2006; 56: 1 ex. 27.8.2001 (LT); 61 (Shutova 2008).

*Epinotia immundana (F. v. R.). 34: 1 ex. 3.7.2006. The northernmost record in Finland from $\mathrm{Li}$ (Kullberg et al. 2010).

Epinotia nisella (Cl.). 38-1: 2 exx. 23.7.2000; 43-

7: 2 exx. 23.7.2000; 44: 2 exx. 18.9.2000 (LT);

55: 7 exx. 29.8.2000 (LT); 56: 1 ex. 29.8.2000

(LT). Was known from 38-1 (erroneously referred to as 39 by Kozlov et al. 2000) and 61 (Shutova 2004).

Epinotia crenana (Hb.). 55: 1 ex. 18.9.2000(LT).

Was known only from 10 (Kozlov \& Jalava 1994).

*Epinotia tenerana (Den. \& Schiff.). 46: 1 ex. 2.8.1921. This specimen served as the basis for the erroneous record (Sinev 2008) of Pelochrista modicana (Z.) from the Murmansk region (S. Nedoshivina, pers. comm.). The northernmost records in Finland from $L e$ and $L i$ (Kullberg et al. 2010).

'Zeiraphera ratzeburgiana (Saxesen). 61 (Shutova 2008).

*Zeiraphera isertana (F.). 43-35: 1 ex. 24.7.2001. The northernmost record in Finland from $\mathrm{Oba}$ (Kullberg et al. 2010).

*Eucosma saussureana (Ben.). 43-9: 1 ex. 21.6.2000; 68: 2 exx. 29.6.2000; 126: 2 exx. 29.6.2000. In Finland recorded only from Obb, Ks, Lkoc, and Lkor (Kullberg et al. 2010).

Epiblema cirsiana (Z.). 43-35: 1 ex. 27.6.2006. Was known only from 55 (Kozlov \& Jalava 1994).

Coccyx posticana (Zett.). 43-5: 1 ex. 4.7.2001. Was known from 12 and 67 (Kozlov \& Jalava 1994).

Cydia nigricana (F.). 117: 1 ex. 10.7.2009. This record extends the northern limit of this species, which was known only from 89 (Kozlov \& Kullberg 2006).

*Cydia duplicana (Zett.). 43-5: 1 ex. 24.6.2004; 55: 1 ex. 20.7.2000 (LT); 56: 2 exx. 27.6.7.7.2001 (LT). The northernmost record in Finland from $L i$ (Kullberg et al. 2010).

*Cydia cognatana (Barret). 109-10: 1 ex. 6.7.2004. The northernmost records in Finland from $L e$ and $L i$ (Kullberg et al. 2010).

*Cydia cornucopiae (Tengstr.). 38-1: 1 ex. 
22.6.2006. The northernmost record in Finland from $O b b$ (Kullberg et al. 2010).

${ }^{\circ}$ Grapholitha tenebrosana (Dup.). 61 (Shutova 2008); we have examined a photograph of this specimen.

${ }^{\circ}$ Lathronympha strigana (F.). 61 (Shutova 2008); 71: 1 ex. 20.7.2004.

*Pammene obscurana (Steph.). 71: 2 exx. 20.7.2004; 74: 1 ex. 4.7.2003. The northernmost records in Finland from $O b a$ and $O b b$ (Kullberg et al. 2010).

'Dichrorampha vancouverana (McD.). 61 (Shutova 2008, as D. gueneeana).

*Dichrorampha petiverella (L.). 43-5: 1 ex. 24.6.2005. The northernmost record in Finland from Ok (Kullberg et al. 2010).

\section{Choreutidae}

${ }^{\circ}$ Choreutis diana (Hb.). 38-1: 1 ex. 28.7.2005; 43-29: 1 ex. 22.7.2006 (ex 1. on birch, Betula pubescens); 46: 12 exx. 1931-1932 (Sinev 2008, and pers. comm.).

\section{Epermeniidae}

*Phaulernis dentella (Z.). 114: 1 ex. 8.7.1999. The northernmost records in Finland from $K b$ and $O m$ (Kullberg et al. 2010).

\section{Pterophoridae}

* Platyptilia gonodactyla (Den. \& Schiff.). 56: 2 exx. 11.-31.7.2000 (LT). Record from 83 (Shutova et al. 1999) is based on an erroneous determination; it was withdrawn by the author (Shutova 2004). The record by Sinev (2008) is based on specimens collected from Northern Karelia (V. Kovtunovich, pers. comm.). The northernmost records in Finland from Lkor and $L i$ (Kullberg et al. 2010).

Stenoptilia veronicae Karv. 55: 2 exx. 19.29.8.2000 (LT). The northernmost record; was known only from the White Sea shore (Kozlov et al. 2000).

*Geina didactyla (L.). 44: 1 ex. 21.7.2000 (LT); 56: 1 ex. 31.7.2000 (LT). The northernmost records in Finland from $\mathrm{Ok}$ and $\mathrm{Oba}$ (Kullberg et al. 2010).

\section{Pyralidae}

-Ortholepis betulae (Goeze). 67 (Shutova 2004). Assara terebrella (Zinck.). 74: 2 exx. 21.7.3.8.2004 (LT). Was known only from 43-29 (Kozlov \& Jalava 1994).

Agriphila straminella (Den. \& Schiff.). 111: 1 ex. 16.7.2006. The northernmost record; was known from the White Sea shore and mouth of the Ponoi River (Kozlov \& Jalava 1994)

!Chrysoteuchia culmella (L.). 43-35: 5 exx. 27.6.2006; 68: 1 ex. 27.6.2002; 74: 1 ex. 4.7.2003, 1 ex. 29.6.2004 (LT); 82-BV (Shutova 2004); 118: 1 ex. 10.7.2009; 121: 4 exx. 10.-12.7.2009. Was reported from 28 (Krogerus 1943).

Crambus heringiellus H.-S. 121: 1 exx. 10.12.7.2009. The northernmost record; was known only from 95 (Kozlov \& Kullberg 2006). Record from 82 (Shutova et al. 1999) withdrawn by Shutova (2004).

${ }^{\circ}$ Elophila nymphaeata (L.). 85-VE (Shutova et al. 1999).

${ }^{\circ}$ Evergestis aenealis (Den. \& Schiff.). 83-BL (Shutova et al. 1999).

*Udea prunalis (Den. \& Schiff.). 113: 1 ex. 8.7.2000. The northernmost records in Finland from $O b b$ and $K s$ (Kullberg et al. 2010).

*Sitochroa verticalis (L.). 71: 1 ex. 20.7.2004. The northernmost record in Finland from $K b$ (Kullberg et al. 2010).

*Pleuroptya ruralis (Scop.). 44: 4 exx. 6.16.9.2001 (LT); 55: 3 exx. 16.8.2001 (LT); 56: 2 exx. 16.-27.8.2001 (LT); 60, 61 (Shutova 2008, as Paratalanta hyalinalis); 74: 8 exx. 31.8.-14.9.2004 (LT). The northernmost record in Finland from Le (Kullberg et al. 2010).

\section{Lasiocampidae}

!Eriogaster lanestris (L). 43-14, 43-41: larval nests on birch (Betula pubescens) in late summer of 2005; 44 and Salnye tundry (Kataev \& Berlina 2006); 83, 84 (Shutova et al. 1999, Shutova 2004). Earlier records from 9, 18 and 20 were made $50-80$ years ago (Valle 1933, Nordström et al. 1961, Heath \& Leclercq 1981).

\section{Saturniidae}

Saturnia pavonia (L.). 43-9: 1 ex. 15.6.2004. Interestingly, the population discovered in the early 1990s (Kozlov \& Jalava 1994) still persists here, although the locality was gradually transformed from birch woodland into industrial barren due to severe pollution impact.

\section{Sphingidae}

'Sphinx pinastri L. 68, 85-VE (Shutova et al. 1999).

${ }^{\circ}$ Hemaris fuciformis (L.). 84-GO (Shutova 2004). 


\section{Papilionidae}

Papilio machaon L. 39-1, 43-9, 43-11, 43-15, 4347. The species was surprisingly common in 2001.

\section{Pieridae}

${ }^{\circ}$ Pieris daplidice (L.). 61 (Shutova 2004). The record of P. edusa (F.) by Sinev (2008) is likely to be based on this publication.

${ }^{\circ}$ Gonepteryx rhamni (L.). 84, 85-VE (Shutova 2004).

${ }^{\circ}$ Colias hecla Lefebvre. 46: 1 ex. 3.7.1959 (Tuzov et al. 1997, Table 37 fig. 1). Records from the northern part of the Murmansk region (Gorbunov 2001), which were repeated by Lvovsky \& Morgun (2007), are based on doubtful information (P. Gorbunov, pers. comm.).

\section{Lycaenidae}

!Plebeius eumedon (Esp.). 43-35: 1 ex. 14.7.2004; 44: 1 ex. 11.7.1990. The first records from the central part of the Kola Peninsula; was known from 59 (Nordström et al. 1955), 61, 83, 84, 85-VE (Shutova et al. 1999).

${ }^{\circ}$ Plebeius argus (L.). 46: 2 exx. 15-16.7.2004 (Lvovsky \& Morgun 2007, and pers. comm.). Earlier doubtful records were discussed by Kozlov \& Jalava (1994). The record by Makarova (2005) is also likely to be based on an erroneous identification.

${ }^{\circ}$ Aricia artaxerxes (F.). 28: 1 ex. 6.7.1940; 115: 2 exx. 7.2004 (Lvovsky \& Morgun 2007, and pers. comm.). The source of an earlier report from the northern Kola Peninsula (Gorbunov 2001) cannot be recovered (P. Gorbunov, pers. comm.).

\section{Nymphalidae}

${ }^{\circ}$ Nymphalis io (L.). 61 (Shutova 2008); 126: 1 ex. 13.7.2006. This species is recently spreading to the north: by 2000, the northernmost record in Finland was from $\mathrm{Obb}$; however, since then the species was recorded as migrant in $K s$ and Li (Kullberg et al. 2010).

Lasiommata petropolitana (F.). 43-5: 1 ex. 22.6.2006; 43-9: 2 exx. 20.6.2003, 4 exx. 6.7.2005, 7 exx. 22.6.-8.7.2006; 61: 1 ex. 21.6.2003; 68: 2 exx. 29.6.2000; 81 (Shutova 2004); 119: 1 ex. 10.7.2009. From the 1980s to the early 1990s the species was restricted to the southernmost part of the Murmansk region
(Kozlov 1983, Kozlov \& Jalava 1994). In the central part of the Kola Peninsula it was for the first time found in a small river valley at the external border of industrial barrens in 2003. Since then, the species was observed almost every year, and another local population was discovered in 2006, also in industrial barren.

${ }^{\circ}$ Coenonympha pamphilus (L.). 59: 1 ex. 11.7. 1980. This record was published by Kozlov (1983) but overlooked by Kozlov \& Jalava (1994); the specimen was rediscovered by Lvovsky \& Morgun (2007). The presence of this species in the north-western part of the Murmansk region was also reported by Heath \& Leclercq (1981), but the source for this information remains unknown.

\section{Drepanidae}

*Tethea or (Den. \& Schiff.). 38-1: 1 ex. 8.7.2006. The northernmost records in Finland from Lkoc and Lkor (Kullberg et al. 2010).

\section{Geometridae}

Epirrhoe hastulata (Hb.) 123: 1 ex. 12.7.2009. Was known only from two specimens collected long ago in 28 and 64 (Kozlov \& Jalava 1994).

${ }^{\circ}$ Mesoleuca albicillata (L.). 85-VE (Shutova 2004).

'Lampropteryx otregiata (Metcalfe). 84 (Shutova et al. 1999).

*Dysstroma latefasciatum (Prout). 56: 1 ex. 19.8.2000 (LT). The northernmost record in Finland from Ks (Kullberg et al. 2010).

*Chloroclysta miata (L.). 74: 1 ex. 8.-9.2006 (LT). The northernmost record in Finland from Ks (Kullberg et al. 2010).

'Plemyria rubiginata (Den. \& Schiff.). 61 (Shutova 2004).

* Thera firmata (Hb.) 74: 3 exx. 31.8.-14.9.2004 (LT). The northernmost record in Finland from Ks (Kullberg et al. 2010).

${ }^{\circ}$ Thera obeliscata (Hb.). 61, 83-RJ, 83-VE (Shutova et al. 1999, Shutova 2008). An earlier record from the Kola Peninsula (Mikkola et al. 1989) was based on a specimen collected in Finland, NE part of the province Lkem (Kozlov \& Jalava 1994).

${ }^{\circ}$ Thera juniperata (L.). 61 (Shutova et al. 1999). Same as T. obeliscata.

*Mesotype didymata (L.). 74: 4 exx. 3.-15.8. 2004 (LT). The northernmost records in Fin- 
land from Lkor and Le (Kullberg et al. 2010).

${ }^{\circ}$ Eupithecia fennoscandica Knaben. 46: 1 ex. 26.6.1935 (Sinev 2008; V. Mironov, pers. comm.).

${ }^{\circ}$ Eupithecia actaeata Walderdorff. 84-GO (Shutova et al. 1999).

${ }^{\circ}$ Eupithecia assimilata Doubl. 55: 8 exx. 19.7.6.8.2001 (LT) (Sinev 2008).

${ }^{\circ}$ Eupithecia icterata (Vill.). 82 (Shutova et al. 1999).

${ }^{\circ}$ Eupithecia succenturiata (L.). 61, 83-VE (Shutova 2008).

!Eupitecia indigata (Hb.). 43-14: 1 ex. 22.6. 2006. Was reported from 18 (Valle 1933).

${ }^{\circ}$ Eupithecia nanata (Hb.). 126: 1 ex. 29.6.2000 (Sinev 2008).

Eupithecia veratraria arctica Viid. 56: 1 ex. 16.7.2001 (LT). Was known only from one specimen collected in 65 in 1899 (Kozlov \& Jalava 1994). Recently found in Northern Norway (Tammaru et al. 1995).

${ }^{\circ}$ Eupithecia tantillaria Boisd. Reported for the Murmansk region by Sinev (2008); however, the source of information cannot be recovered (V. Mironov, pers. comm.).

${ }^{\circ}$ Pasiphila debiliata $(\mathrm{Hb}$.). Reported for the Murmansk region by Sinev (2008); however, the source of information cannot be recovered (V. Mironov, pers. comm.).

${ }^{\circ}$ Trichopteryx carpinata (Borkh.). 61 (Shutova 2008).

${ }^{\circ}$ Odontopera bidentata (Cl.). 84-GO (Shutova et al. 1999).

Plagodis pulveraria (L.). 68: 1 ex. 29.6.2000; 112 (Shutova 2008); 124: 1 ex. 11.7.2007. Was known only from 64a (Kozlov \& Jalava 1994).

${ }^{\circ}$ Pasiphila chloerata (Mabille). 61 (Shutova 2004).

Macaria notata (L.). 38-1, 43-5, 43-7, 43-9, 4314, 43-29, 44, 56a, 70: total of 44 exx. collected during 2001-2006. Was known only from the Petsamo area (Kozlov \& Jalava 1994).

Chiasmia clathrata (L.). 119: 1 ex. 10.7.2009. The northernmost record; was known from 58a and 67 (Kozlov \& Jalava 1994).

Arichanna melanaria (L.): 38-11: 1 ex. 12.8. 2007. The northernmost record; was known only from the White Sea shore (Kozlov et al. 2000).

\section{Notodontidae}

Clostera pigra (Hufn.). 38-1: 1 ex. 24.6.2004. Was known from 46 (Fridolin 1936), 55 (Kozlov \& Jalava 1994) and 61 (Shutova 2004).

${ }^{\circ}$ Notodonta torva (Hb.). 55: 1 ex. 30.6.2000 (LT); 84 (Shutova 2004).

!Notodonta dromedarius (L.). 38-1: 1 ex. 8.7.2006; 61 (Shutova 2004). The earlier records from 6, 9 and 46 were made some 50-70 years ago (Kozlov \& Jalava 1994).

\section{Lymantriidae}

Orgya antiqua (L.). 66: 1 ex. 11.8.2008 (larva on Rumex sp.). Was known only from 84-GO (Kozlov et al. 2000).

!Dicallomera fascelina (L.). 39-15: 1 ex. 7.8.2006 (larva on Betula pubescens). The earlier record from 46 was made over 60 years ago (Kozlov \& Jalava 1994).

\section{Nolidae}

!Nola karelica Tengstr. 43-14: 1 ex. 24.7.2004; 61 (Shutova 2004). The earlier records from 9 , 27 and 28 were made some $50-70$ years ago (Kozlov \& Jalava 1994).

\section{Arctiidae}

${ }^{\circ}$ Grammia quenseli (Payk.). Reported for the Murmansk region by Sinev (2008) on the basis of 1 specimen collected on 13.7.1928 in stony tundra between the Iokanga River and Iokanga depression (V. Dubatolov, pers. comm.). Since the exact position of this locality cannot be identified, we refrain from providing it with numerical code.

\section{Noctuidae}

${ }^{\circ}$ Rivula sericealis (Sc.). 61 (Shutova 2008); we have examined a photograph of this specimen.

Hypenoides humidalis Doubl. 43-29: 1 ex. 24.7. 2001, 1 ex. 31.7.2006; 43-35: 1 ex. 24.7.2001, 1 ex. 4.8.2005; 61 (Shutova 2008). Was known only from 62 (Kozlov \& Jalava 1994). Also found in Northern Karelia (Nilmoguba, 2 exx. 14.7.2000).

${ }^{\circ}$ Hypena crassalis (F.). 61, 68 (Sviridov et al. 2006); 83 (Shutova 2008).

Callistege mi (Cl.). 68: 1 ex. 29.6.2000. Was known only from 84-GO (Kozlov et al. 2000).

${ }^{\circ}$ Deltote uncula (Cl.). 61 (Shutova 2008); we have examined a photograph of this specimen.

'Polychrysia moneta (F.). 61 (Sviridov \& Shutova 2002); 74: 1 ex. 8.-9.2006 (LT). 
'Diachrysia tutti (Kostrowicki). 60 (Shutova 2008); 61 (Sviridov et al. 2006, as D. stenochrysis (Warren)).

Plusia festucae (L.). 38-1: 1 ex. 24.7.2001. This specimen was collected in the same locality (heavily polluted industrial barren) where the species was discovered in 1991 (Kozlov \& Jalava 1994), indicating long-term persistence of the population.

Autographa gamma (L.). 55: 3 exx. 29.8.8.9.2000 (LT); 68: 1 ex. 29.6.2000. Was known from 9 (Valle 1933), 60, 61, 84-GO (Kozlov et al. 2000); occasional migrant.

*Autographa pulchrina (Hw.). 55: 1 ex. 20.7.2000 (LT). The northernmost records in Finland from Lkoc and Lkor (Kullberg et al. 2010).

'Autographa excelsa (Kretschmar). 61, 68 (Sviridov et al. 2006).

${ }^{\circ}$ Colocasia coryli (L.). 39: 2 exx. 7.8.2006 (larvae on Betula pubescens), 2 exx. 18.8.2008 (larvae on B. pubescens); 44: 1 ex. 15.8.2006 (larva on $B$. pubescens); 61 (Sviridov \& Shutova 2002).

-Acronicta cinerea (Hufn.). 84-GO (Shutova et al. 1999).

-Amphipyra tragopoginis (Cl.). 60 (Sviridov et al. 2006); 61 (Shutova 2008).

${ }^{\circ}$ Xanthia icteritia (Hufn.). 44: 2 exx. 14.8.16.9.2001 (LT), 1 ex. 10.8.2005, Kataev \& Berlina (2006); 55: 1 ex. 16.8.2001 (LT); 61 (Sviridov \& Shutova 2002).

${ }^{\circ}$ Agrochola circellaris (Hb.). 55: 1 ex. 28.9.2000

(LT); 61 (Sviridov \& Shutova 2002).

Apamea furva (Den. \& Schiff.). 74: 1 ex. 8.-9. 2006 (LT). Was known only from 61 (Kozlov et al. 2000).

Celaena haworthi (Curt.). 44: 4 exx. 29.8.8.9.2000 (LT). Was known only from 61 (Kozlov et al. 2000).

${ }^{\circ}$ Celaena leucostigma (Hb.). 61 (Sviridov \& Shutova 2002); 74: 3 exx. 31.8.-14.9.2004 (LT).

-Sedina pygmina (Haw.). 61 (Sviridov et al. 2006).

${ }^{\circ}$ Arenostola phragmitidis (Hb.). 61 (Sviridov et al. 2006).

${ }^{\circ}$ Mythimna pallens (L.). 61 (Sviridov \& Shutova 2002).

${ }^{\circ}$ Mythimna comma (L.). Reported for the Mur- mansk region by Sinev (2008); however, the source of information cannot be recovered (A. Matov, pers. comm.).

${ }^{\circ}$ Lasionycta secedens (Wlk.). 83 (Shutova et al. 1999).

${ }^{\circ}$ Diarsia dahlii (Hb.). 61 (Shutova 2008); we have examined a photograph of this specimen.

Lycophotia porphyrea (Den. \& Schiff.). 43-14: 1 ex. 8.7.2006. Was known only from 43-41 (Kozlov et al. 2000)

*Xestia sincera (H.-S.). 74: 1 ex. 20.7.2005 (LT); 124: 1 ex. 11.7.2007. The northernmost records in Finland from Lkor and Le (Kullberg et al. 2010).

'Xestia baja (Den. \& Schiff.). 61 (Sviridov et al. 2006); 74: 1 ex. 8.-9.2006 (LT); 83-VE (Shutova 2008).

'Protolampra sobrina (Dup.). 61 (Sviridov \& Shutova 2002).

*Euxoa recussa (Hb.). 74: 2 exx. 3.-15.8.2004 (LT). The northernmost record in Finland from Obb (Kullberg et al. 2010).

\section{Excluded species}

Micropterix aruncella (Scop.). Erroneously indicated for the Murmansk region (Sinev 2008); obviously a technical error. Discovery of this species in the Kola Peninsula seems unlikely, because in Finland it is known only from the southern provinces $\mathrm{Al}$ and $\mathrm{Sa}$ (Kullberg et al. 2010).

Eriocrania unimaculella (Zett.). Indicated for the Murmansk region (Sinev 2008) on the basis of an misidentified specimen of E. salopiella.

Pharmacis carna (Den. \& Schiff.). Mentioned (as Hepialus uralensis Gr.-Gr.) from 46 by Fridolin (1936). This record is presumably based on misidentification of certain forms of common Hepialus fusconebulosus.

Nematopogon metaxellus ( $\mathrm{Hb}$.). Indicated for the Murmansk region (Sinev 2008) after Valle (1933) (S. Sinev, pers. comm.). However, as we commented earlier (Kozlov \& Jalava 1994), the specimen mentioned by Valle (1933) belongs to N. pilellus.

Nemapogon wolffiellus (Karsholt \& Nielsen). Erroneously indicated for the Murmansk region (as N. wolfierella [lapsus calami]: Sinev 2008) 
on the basis of the catalogue by Ershoff \& Field (1870), who reported this species for the Arkhangelsk Gubernia, which at that time included also the Murmansk district (S. Baryshnikova, pers. comm.). However, the only source of information on the moth fauna of the Murmansk district, potentially available to Ershoff and Field (1870), was the paper by Tengström (1869) which did not mention this species. Zagulajev (1964, fig. 87) showed the northern distribution limit of this species within Northern Karelia; in Finland the northernmost records are from the provinces $L k o c$ and $K s$ (Kullberg et al. 2010).

Trichophaga tapetzella (L.). Same as Nemapogon wolffiellus. Record of this species (spelled out as T. tapetiella) from the Petsamo area (Valle 1933) is based on misidentification of $T$. scandinaviella. Occurrence of T. tapetzella in the Kola Peninsula seems unlikely, because in Finland it is known from the southernmost provinces only (Kullberg et al. 2010).

Sideria listerella (L.). Reported from 84 (Shutova et al. 1999); this record most likely served as the basis for a questionable indication for the Murmansk region (Sinev 2008). Examination of the photograph demonstrated that the specimen is misidentified and belongs to Dahlica lazuri. In Finland, the species is confined to the southern provinces (Kullberg et al. 2010); its occurrence in the Kola Peninsula is unlikely.

Phyllonorycter sagitellus (Bjerk.). Mozolevskaya (1999) listed this species as forming an outbreak in the Murmansk region. In Finland, the species is confined to the Southern provinces (Kullberg et al. 2010); its discovery in the Kola Peninsula seems unlikely.

Phyllonorycter populifoliellus (Tr.). Reported from 60 (Shutova 2004). The specimen was found inside a building; the probability of establishment of a local population is low, because larvae of this species feed only on cultivated poplars. In 2010, we did not find mines of this species in 55 and 60, in spite of substantial sampling effort. In Finland the northernost records are from provinces $S b$ and $K b$ (Kullberg et al. 2010).

Phyllonorycter dubitellus (H.-S.). 61 (Shutova 2008). Examination of a photograph demonstrated that this identification is incorrect.
Swammerdammia pyrella (de Villers). Indicated for the Murmansk region (Sinev 2008); however, the source of information cannot be recovered (S. Sinev, pers. comm.). Occurrence of this species in the Kola Peninsula seems unlikely, because in Finland it is known from the two southernmost provinces $(A l, N)$ only (Kullberg et al. 2010). The record concerns most probably either $S$. passerella or $S$. caesiella.

Paraswammerdammia lutarea (Hw.). Reported from 82 (Shutova et al. 1999). Examination of a photograph demonstrated that the specimen was misidentified and belongs to $P$. conspersella. In Finland, the species is confined to the southern provinces, with a recent record from $K b$ (Kullberg et al. 2010); its discovery in the Kola Peninsula seems unlikely.

Glyphipterix forsterella (F.). Indicated for the Murmansk region (Sinev 2008); however, the source of information cannot be recovered (S. Sinev, pers. comm.). Occurrence of this species in Kola Peninsula seems unlikely, because the northernmost records in Finland are from the provinces $\mathrm{Ok}$ and $\mathrm{Oba}$ (Kullberg et al. 2010).

Agonopterix arctica (Strand). Indicated for the Murmansk region (Sinev 2008) after Valle (1933) (A. Lvovsky, pers. comm.). However, as we commented earlier (Kozlov \& Jalava 1994), this identification is doubtful and we found no material of this species in the collection of K. Valle.

Ethmia quadrillella (Goeze). Indicated for the Murmansk region (Sinev 2008) after Dubatolov et al. (1997) who copied distribution data ("everywhere until Khibiny mts.") from Zagulajev (1981). No specimens from the Murmansk region were found in the ZIN collection, and the origin of the information published by Zagulajev (1981) remains unknown. The northernmost record in Finland from the province Le (Kullberg et al. 2010) is based on a single specimen collected in Kilpisjärvi.

Ethmia pusiella (L.). Same as for E. quadrillella (see above). The northernmost record in Finland from the province $K b$ (Kullberg et al. 2010).

Ethmia pyrausta (Pall.). Same as for E. quadrillella (see above). In Finland recorded from the 
provinces $A l$ and $N$ only (Kullberg et al. 2010). Elachista poae Stt. Indicated for the Murmansk region (Sinev 2008) after Valle (1933) (S. Sinev, pers. comm.). However, as we commented earlier (Kozlov \& Jalava 1994), this determination is doubtful and we found no material on this species in the collection of $\mathrm{K}$. Valle. Occurrence of E. poae in the Kola Peninsula seems unlikely, because its host plant, Glyceria maxima, is absent from northern Fennoscandia, including the entire Kola Peninsula (Hultén 1971). In Finland the species is known from the southernmost provinces only (Kullberg et al. 2010).

Mompha propinquella (Stt.). Reported from 61 (Shutova et al. 1999); record withdrawn by Shutova (2004). In Finland, the species is confined to the southern provinces only (Kullberg et al. 2010); most probably the record concerns the superficially similar M. lacteella.

Coleophora betulaenanae Klimesch. Listed by Kozlov \& Jalava (1994) as bona species; these records should be attributed to $C$. vacciniella.

Caryocolum blandellum (Douglas). Reported from 61 (Shutova 2008). Examination of a photographof this specimen demonstrated that this is $C$. blandelloides. The occurrence of $C$. blandellum in the Kola Peninsula seems unlikely, because its host plant, Stellaria holostea, is absent from northern Fennoscandia, including the entire Kola Peninsula (Hultén 1971).

Acleris emargana (F.). Earlier records from 55 and 61 (Kozlov et al. 2000) should be attributed to $A$. effractana (see above).

Acleris shepherdana (Stph.). Reported from 84 (Shutova et al. 1999). Examination of the photographs demonstrated that the specimens are misidentified and belong to $A$. aspersana. In Finland recorded from the southernmost provinces $N$ and $K a$ only (Kullberg et al. 2010); its occurrence in the Kola Peninsula seems doubtful.

Archips podanus (Sc.). Reported from 23 on the basis of leaves of Betula pendula and Sorbus aucuparia with damage caused by some larvae (Mitina \& Kuznetsova 2006). These authors neither reared moths, nor preserved larvae (E. Mitina, pers. comm.). An obvious identification error, it is unlikely that such damage can be attributed to a species. In Finland the species is restricted to the southernmost provinces (Kullberg et al. 2010), and its discovery in Murmansk seems unlikely.

Clepsis pallidana (F.). Indicated for the Murmansk region (Sinev 2008); however, the source of information cannot be recovered (S. Sinev, pers. comm.). Occurrence of this species in the Kola Peninsula seems unlikely, because the northernmost record in Finland is from the province $K b$ (Kullberg et al. 2010).

Aterpia corticana (Den. \& Schiff.). Record of this species (referred to as Argyroploce (Apotomis) corticana $\mathrm{Hb}$.) from the Petsamo area (Valle 1933 ) is based on misidentification of Loxoterma bipunctana.

Apotomis frigidana Packard. Indicated for the Murmansk region (Sinev 2008) after Kuznetsov (1978) who explicitly mentioned the occurrence of $A$. frigidana on the Kola Peninsula. No specimens of this Beringian species from the Murmansk region were found in ZIN collection, and therefore the origin of the information used by Kuznetsov (1978) remains unknown. This species has not been recorded from Finland, Sweden, or Norway (Aarvik 2010).

Pelochrista modicana (Z.). Recorded in the Murmansk region (Sinev 2008) on the basis of an erroneous identification; the specimen appeared to be Epinotia tenerana (S. Nedoshivina, pers. comm.).

Eucosma tripoliana (Barr.). Reported for 61 and 84 (Shutova et al. 1999); records withdrawn by Shutova (2004). This species is absent from Russia and Finland, the nearest records are known from southern Sweden and Denmark (Aarvik 2010).

Cydia pomonella (L.). 60: in a building, presumably emerged from fruits transported from southern regions (Shutova et al. 1999). Although apple (Malus domestica) trees are occasionally grown in the Murmansk region, and even produce small fruits, the thermal requirements for C. pomonella (ca. 600 degree-days over $+10^{\circ} \mathrm{C}$ ) do not allow this species to establish local populations in the Kola Peninsula.

Choreutis pariana (Cl.). Reported from 23 on the basis of leaves of Sorbus aucuparia damaged by some larvae (Mitina \& Kuznetsova 2006). 
The authors neither reared moths, nor preserved larvae (E. Mitina, pers. comm.). An obvious identification error; it is unlikely that such damage can be attributed to a species. In Finland the species is restricted to the southernmost provinces only (Kullberg et al. 2010), and its discovery in Murmansk seems unlikely.

Phaulernis statariella (Heyd.). Record of this species from the surroundings of Murmansk (Djakonov 1911) is most likely based on misidentification of P. fulviguttella.

Platyptilia farfarellus Z. Erroneously indicated for the Murmansk region (Sinev 2008) on the basis of specimens collected from northern Karelia (V. Kovtunovich, pers. comm.). This species has been recorded in Fennoscandia only from Denmark (Gielis 2010) and recently from southernmost Sweden (Gustafsson 2010); a doubtful identification.

Amblyptilia acanthadactyla (Hb.). Reported from 84 (Shutova et al. 1999) and, on the basis of this record, listed by Sinev (2008). Although this species is widely distributed in Europe (Gielis 2010), it was missed from the Finnish fauna until a very recent discovery in southwest Finland (Kullberg et al. 2010). Correctness of the identification was therefore questioned, and after re-examination of the specimen E. Shutova (pers. comm.) confirmed that this record concerns the very similar $A$. punctidactyla, which is common in Finland up to the northernmost regions (Kullberg et al. 2010).

Hellinsia distincta (H.-S.). Indicated for the Murmansk region (Sinev 2008) on the basis of the ZIN collections (P. Ustjuzhanin, pers. comm.). The specimen from 46, found under this label, was identified by $\mathrm{S}$. Tshetverikov as $H$. tephradactyla, and we confirm this identification.

Hellinsia didactylites (Ström). Indicated for the Murmansk region (Sinev 2008) on the basis of the ZIN collections (P. Ustjuzhanin, pers. comm.). However, we were unable to find any specimen originating from the Murmansk region in this collection.

Hellinsia chrysocomae (Rag.). Erroneously indicated for the Murmansk region (Sinev 2008) on the basis of specimens collected from northern Karelia (V. Kovtunovich, pers. comm.). This species has not been recorded from Finland, Sweden, or Norway (Gielis 2010); a doubtful identification.

Paratalanta hyalinalis (Hb.). Reported from 60 and 61 (Shutova 2008). Examination of the photographs demonstrated that the specimens are misidentified and belong to Pleuroptya ruralis.

Zophodia grossulariella $\mathrm{Hb}$. Reported from 61 (Shutova et al. 1999) on the basis of an erroneous identification; this specimen appeared to be Phycitodes binaevellus (Kozlov et al. 2000). Record withdrawn by Shutova (2004).

Udea elutalis (Den. \& Schiff.). Reported from 83-BL (Shutova et al. 1999); record withdrawn by Shutova (2004).

Euthrix potatoria (L.). Erroneously indicated for the Murmansk region (Sinev 2008) after Sviridov (1970) who referred to specimens collected from northern Karelia.

Pyrgus malvae (L.). Indicated (as a questionable record) for the Murmansk region (Sinev 2008) on the basis of extrapolation of species' distribution in Scandinavia (A. Devyatkin, pers. comm.). The northernmost records in Finland are from the provinces $O m$ and $O k$ (Kullberg et al. 2010).

Thymelicus lineola (Ochs.). Same as P. malvae (see above). In the Republic of Karelia it reaches $62^{\circ} \mathrm{N}$ latitude (Lvovsky \& Morgun 2007); the northernmost records in Finland are from the provinces $\mathrm{Ok}$ and $\mathrm{Oba}$ (Kullberg et al. 2010).

Ochlodes sylvanus (Esp.). Same as P. malvae (see above). In the Republic of Karelia it reaches $64^{\circ} \mathrm{N}$ latitude (Lvovsky \& Morgun 2007); the northernmost record in Finland is from the province Obb (Kullberg et al. 2010).

Cupido minimus (F.). Indicated for the Murmansk region (Sinev 2008) after Lvovsky \& Morgun (2007) who extracted information from the distribution map published by Gorbunov (2001). The reliability of this information is doubtful, since it was received from an amateur lepidopterologist whose name cannot be recovered (P. Gorbunov, pers. comm.). Although this species was once recorded from the province Le in Finland (Kullberg et al. 2010), and the species' distribution reaches as 
far north as Tromsö in Norway (Aarvik et al. 2000), it is generally confined to the more southern regions.

Agriades orbitulus (Püngeler). Reported from the Murmansk region (Tuzov et al. 2000) on the basis of one specimen labelled "Lapponia"; this record was mentioned by Lvovsky \& Morgun (2007) and Sinev (2008). There is little reason to believe that this label refers to the Murmansk region; since this species had not been recorded from Finland, the specimen is likely to originate from more southerly mountain regions in Sweden or Norway.

Brenthis ino (Rott.). Erroneously indicated for the Murmansk region (Sinev 2008) on the basis of specimens collected from northern Karelia (D. Morgun, pers. comm.).

Boloria improba (Butl.). Indicated for the Murmansk region by Gorbunov (2001) on the basis of doubtful information (see above, comment to Cupido minimus).

Lasiommata maera (L.). Reported, on the basis of visual observations, from 44 (Kataev \& Berlina 2006). In Finland this species is distributed northwards up to the provinces $\mathrm{Om}$ and $O k$ (Kullberg et al. 2010); its occurrence in the Kola Peninsula seems unlikely. This record is almost certainly based on an erroneous determination of $L$. petropolitana.

Erebia polaris Stgr. Indicated for the Murmansk region (Sinev 2008) after Lvovsky \& Morgun (2007) who extracted information from the distribution map published by Gorbunov (2001). The source of this information cannot be recovered.

Xanthorhoe incursata $(\mathrm{Hb}$.). Record of this species from the surroundings of Murmansk (Djakonov 1911) is most likely based on misidentification of $X$. annotinata.

Ecliptoptera capitata (H.-S.). Reported from 61 and 84 (Shutova et al. 1999). However, this species is monophagous on Impatiens nolitangere, which is absent in northern Fennoscandia, including the entire Kola Peninsula (Hultén 1971). Correctness of the identification was therefore questioned, and after re-examination of the specimen E. Shutova (pers. comm.) confirmed that this record concerns E. silaceata.
Horisme aemulata $(\mathrm{Hb}$.). Reported from 84-GO (Shutova et al. 1999) on the basis of erroneous determination; this specimen appeared to be H. tersata (Kozlov et al. 2000).

Gynaephora selenitica (Esp.). Indicated for the Murmansk region (Sinev 2008); however, the source of information cannot be recovered (A. Matov, pers. comm.). Occurrence of this species in the Kola Peninsula seems unlikely, because in Finland it is known from the southernmost provinces only (Kullberg et al. 2010).

Cybosia mesomella (L.). Indicated (as a questionable record) for the Murmansk region (Sinev 2008); however, the source of information cannot be recovered. Occurrence of this species in the Kola Peninsula seems unlikely, because the northernmost records in Finland are from the provinces $\mathrm{Ok}$ and $\mathrm{Oba}$ (Kullberg et al. 2010).

Arctia caja (L.). Erroneously indicated for the Murmansk region (Sinev 2008) on the basis of a female collected in Munosero, southern Karelia (V. Dubatolov, pers. comm.).

Diaphora mendica (Cl.). Erroneously indicated for the Murmansk region (Sinev 2008) on the basis of specimens collected in Munosero, southern Karelia (V. Dubatolov, pers. comm.).

Spilosoma lubricipedum (L.). Erroneously indicated for the Murmansk region (Sinev 2008) on the basis of specimens collected in Munosero, southern Karelia (V. Dubatolov, pers. comm.).

Acronicta megacephala (Den. \& Schiff.). Erroneously indicated for the Murmansk region (Sinev 2008) after Sviridov (1970) who referred to specimens collected in northern Karelia. Ironically, Sviridov et al. (2009) referred to Sinev (2008) as to the source of information about the discovery of this species in the Murmansk region.

Acosmetia caliginosa ( $\mathrm{Hb}$.). Erroneously indicated for the Murmansk region (Sinev 2008) after Shutova et al. (1999) who referred to specimens collected in northern Karelia. A doubtful determination (A. Matov, pers. comm.); the distribution range of the foodplant, saw-wort (Serratula tinctoria), is some $1,000 \mathrm{~km}$ to the south from the sampling locality. Sviridov et al. (2009) referred to Sinev (2008) as to the source of information about 
the discovery of this species in the Murmansk region.

\section{Discussion}

The records for 124 species that are new for the regional fauna increased the total number of species found in the Murmansk region to 813 . Among these new records, 82 species were already reported by Russian scientists (partially on the basis of our material). We have not seen any specimen of 44 species reported by Russian scientists as new for the regional fauna; in line with the earlier practice (Kozlov \& Jalava 1994) these records require confirmation. Thus, to date the records of 50 species are based on data from previous publications only, because 26 of these 32 tentative records summarised by Kozlov \& Jalava (1994) have already been confirmed.

Sinev (2008) concluded that the fauna of moths and butterflies of the Murmansk region, with 461 species of "microlepidoptera" and 272 species of "macrolepidoptera" (as reported in the Catalogue of the Lepidoptera of Russia), is best studied among the regions of Russia. He based this conclusion on the ratio between the numbers of "micros" and "macros": the value of 1.695 is highest among the 40 regions, and exceeds the average ratio (0.694) by a factor of 2.5. Changes reported in this paper increased the regional fauna to 813 species, but decreased this ratio to 1.525 . The decrease is associated with the wide use of light traps, which resulted in the capture of many species of "macros" which are difficult to collect by other methods.

The primary reason of the high rate of new faunistic records from the Kola Peninsula during two past decades is the intensive exploration of the regional fauna, in particular by collecting in previously unexplored areas. However, appearance of new species in well-studied sampling sites hints that many moths and butterflies are expanding to the North. This tendency seems to be widespread in Northern Europe, as can be seen in particular from the updates to the provincial records of the Finnish moths and butterflies (Kullberg et al. 2010). This was in particular the case with Lasiommata petropolitana which expanded some $100 \mathrm{~km}$ northwards in the early $2000 \mathrm{~s}$, and with Ypsolopha parenthesella which suddenly became abundant in birch forests around Monchegorsk in 2005-2006.

Intriguingly, nine of the 124 species discovered in the Kola Peninsula during the last decade were collected in industrial barrens - seemingly lifeless habitats surrounding major non-ferrous industries located in Nikel, Zapolyarnyy, and Monchegorsk (Kozlov \& Zvereva 2007). These findings indicate that for some insect species this heavily contaminated, but xerothermic environment is more suitable than undisturbed forest habitats. Populations of several infrequent species, such as Sesia bembeciformis, Ancylis laetana, Plusia festucae, Saturnia pavonia, and Lasiommata petropolitana, persist in barren habitats for decades, sometimes reaching high densities. Some possible explanations for this phenomenon may be the on average higher summer temperatures in barren sites (discussed by Kozlov \& Zvereva 2007) and the lower pressure from natural enemies (Zvereva \& Kozlov 2000, 2006).

The rate of discovery of new species in the fauna of the Kola Peninsula since the publication of our first list (Kozlov \& Jalava 1994) remained relatively high until very recently: 109 new species were collected during 1995-2000 (Kozlov et al. 2000; Shutova et al. 1999) and 114 new species - during the years 2001-2009 (Sviridov \& Shutova 2002, Shutova 2004, 2008, Kozlov \& Kullberg 2006, 2008, Sviridov et al. 2006, and the present paper). If the accumulation of new records continues with approximately the same rate (which obviously is influenced by sampling effort), then the list of moths and butterflies of the Kola Peninsula is likely to reach some 1000 species by the years 2020-2025. The greatest number of new records is expected from the southernmost part of the region, as well as from the White Sea shore. The mouth of Ponoi river, where we could expect to find more eastern arctic species known to occur west of Ural mountains, remains the most critical "blank spot" in the Murmansk region.

On the other hand, we excluded from the regional fauna 60 species reported by different researchers. The most frequent reasons of exclusion were erroneous identifications (confirmed for 18 species and presumed for 12 species) and incorrect interpretation of label data (13 species). 
Unfortunately, 37 of these 61 erroneous records appeared in the first comprehensive checklist of Russian moths and butterflies (Sinev 2008). In contrast to the comments by Bolshakov (2008) and Sviridov et al. (2009), who criticized the authors of this checklist mostly for missing records that have already been published (i.e., for false negative records), we would like to attract attention of lepidopterologists to the urgent need to stop spreading and citing false positive records (some of which are listed above) across future publications.

Acknowledgements. We are thankful to A. Lvovsky, E. Melnikov and V. Zverev for assistance in collecting, and to S. Shestakov and V. Zhirov for permissions to operate light traps in the Lapland Biosphere Reserve and the Polar-Alpine Botanical Garden. Special thanks to T. Konovalova for assistance in operating the light trap at Varzuga. We are indebted to L. Kaila, A. Lvovsky, V. Mironov and E. van Nieukerken for identification of difficult taxa, and to V. Anikin, S. Baryshnikova, A. Devyatkin, E. Gilyazova, P. Gorbunov, V. Dubatolov, A. Koryakin, V. Kovtunovich, A. Lvovsky, A. Matov, V. Mironov, E. Mitina, D. Morgun, S. Nedoshivina, Yu. Nekrutenko, M. Ponomarenko, A. Popova, A. Przhiboro, E. Shutova, S. Sinev, V. Tshikolovets, V. Tuzov, and P. Ustjuzhanin for providing additional information. Special thanks due to Erik J. van Nieukerken for numerous helpful suggestions and improving the language. This work was made possible due to financial support from the EC through the BALANCE project (EVK22002-00169), Maj \& Tor Nessling Foundation, NordForsk (through the visiting professorship grant to M. Kozlov), Percy Sladen Memorial Fund, and the Academy of Finland (projects 200724, 211734, 122133, 124152, 126045, and the researcher exchange grants).

\section{References}

Aarvik, L. E. 2010: Fauna Europaea: Tortricidae. — In: Karsholt, O. \& Nieukerken, E. J. van (eds.), Fauna Europaea: Lepidoptera, Moths. Fauna Europaea version 2.1. [www document]. URL http://www.faunaeur.org/. (Site visited on 18 January, 2010).

Aarvik, L. E., Berggren, K. \& Hansen, L. O. 2000: Catalogus Lepidopterorum Norvegiae. - Lepidopterologisk arbeidsgruppe, Zoologisk museum, Universitetet i Oslo og Norsk institutt for skogforskning, Ås. 192 p.

Bolshakov, L. V. 2008: (Book review: Catalogue of the Lepidoptera of Russia / Sinev S. Yu., ed. - SPb.-M.: KMK, 2008. - 424 p.) — Eversmannia 15-16: 93-97. [In Russian.]

Djakonov, A. M. 1911: (Notes on the Lepidoptera of Murmansk coast). - Russian Entomological Review 11: 13-17. [In Russian.]
Dubatolov, V. V., Ustjuzhanin, P. Ya. \& Zintshenko, V. K. 1997: A review of the Ethmiidae of the Asian part of Russia and neighbouring territories. - Atalanta 28: 161-171.

Erschoff, N. \& Fild, A. 1870: Catalogus lepidopterorum imperii Rossici. - Proceedings of the Russian Entomological Society 4: 130-205.

Fridolin, V. Ju. 1936: (Community of animals and plants of Khibiny mountain area. Biocenotical investigations in 1930-1935.) - Academy of Sciences of the USSR, Moscow \& Leningrad. 295 p. [In Russian.]

Gielis, C. 2010: Fauna Europaea: Pterophoridae. — In: Karsholt, O. \& Nieukerken, E. J. van (eds.), Fauna Europaea: Lepidoptera, Moths. Fauna Europaea version 2.1. [www document]. URL http://www.faunaeur.org/. (Site visited on 18 January, 2010).

Gorbunov, P. Y. 2001: The butterflies of Russia: Classification, genitalia, keys for identification. - Thesis, Ekaterinburg. $320 \mathrm{p}$.

Gustafsson, B. 2010: Svenska fjärilar - Lepidoptera [www document]. URL http://www2.nrm.se/en/ svenska fjarilar/. (Site visited on 20 February, 2010).

Heath, J. \& Leclercq, J. (eds.) 1981: Provisional atlas of the invertebrates of Europe: Maps 1-27. — ITE, Abbots Ripton. 64 p.

Hultén, E. 1971: Atlas över växternas utbredning i Norden: fanerogamer och ormbunksväxter $=$ Atlas of the distribution of vascular plants in northwestern Europe, $2^{\text {nd }}$ edn. - Generalstabens Litografiska Anstalt, Stockholm. 531 p.

Karsholt, O., Aarvik, L., Agassiz, D., Huemer, P. \& Tuck, K. 2005: Acleris effractana (Hübner, 1799) - a Holarctic tortricid. — Nota Lepidopterologica 28: 93 102.

Kataev, G. D. \& Berlina, N. G. 2006: (Addition to the fauna of moths and butterflies (Lepidoptera) of the Lapland reserve, Murmansk district.) - In: Evsyukov, V. I. (ed.), (Entomological research in Northern Asia. Materials of $7^{\text {th }}$ international meeting of entomologists from Siberia and Far East, 20-24 September 2006: 82-83.) Siberian Branch of the Russian Academy of Sciences, Novosibirsk. [In Russian.]

Kozlov, M. V. 1983: (Butterflies (Lepidoptera, Rhopalocera) of Murmanskaya oblast.) - Manuscript 822-B95 deposited in All-Union Institute for Scientific and Technical Information. Leningrad State University, Leningrad. 15 p. [In Russian.]

Kozlov, M. V. \& Jalava, J. 1994: Lepidoptera of Kola Peninsula, Northwestern Russia. — Entomologica Fennica 5: 65-85.

Kozlov, M. V., Jalava, J. \& Shutova, E. 2000: New records of Lepidoptera from the Kola Peninsula, Northwestern Russia. - Entomologica Fennica 11: 131-136.

Kozlov, M. V. \& Kullberg, J. 2006: Lepidoptera of Terskij seashore of the Kola Peninsula, Northwestern Russia. — Entomologica Fennica 17: 123-129.

Kozlov, M. V. \& Zvereva, E. L. 2007: Industrial barrens: extreme habitats created by non-ferrous metallurgy. Reviews in Environmental Science and BioTechnology 6: 231-259. 
Kozlov, M. V. \& Kullberg, J. 2008: Lepidoptera of tundra habitats of the northern Kola Peninsula, Northwestern Russia. - Entomologica Fennica 19: 114-121.

Krogerus, H. 1943: Lepidopterologiska studier i södra Petsamo. - Notulae Entomologicae 23: 19-43.

Kullberg, J., Albrecht, A., Kaila, L. \& Varis, V. 2002: Checklist of Finnish Lepidoptera - Suomen perhosten luettelo. - Sahlbergia 6: 45-190.

Kullberg, J., Albrecht, A., Kaila, L. \& Varis, V. 2010: Checklist of Finnish Lepidoptera - Suomen perhosten luettelo. - [www document]. URL http://www.luomus.fi/elaintiede/hyonteiset/perhoset/ (Site visited on 18 January, 2010).

Kuznetsov, V. I. 1978: (Fam. Tortricidae (Olethreutidae, Cochylidae) - Leafrollers.) - In: Falkovich, M. I. \& Medvedev, G. S. (eds.), (Keys for to the insects of the European part of the USSR.) Vol. 4. Lepidoptera, pt. 1: 163-180. Leningrad, Nauka. [In Russian.]

Lvovsky, A. L. 1988: Broad-winged moths (Leopidoptera, Oecophoridae) of northern Eurasia. - In: Zlobin, V. $\mathrm{V}$. (ed.), The connections between entomofauna of North Europe and Siberia: 84-89. Zoological Institute, Leningrad. 188 p. [In Russian.]

Lvovsky, A. L. \& Morgun, D. V. 2007: Butterflies of Eastern Europe. - Moscow, KMK press. 443 p. [In Russian.]

Makarova, O. A. 2005: (Annals of nature of Pasvik State Nature Reserve. Vol. 9.) - Ryazan State Pedagogical University, Ryazan. 149 p. [In Russian.]

Mikkola, K., Jalas, J. \& Peltonen, O. 1989: Lepidoptera of Finland. Geometridae 2. - Suomen Perhostutkijain Seura ry., Helsinki. 280 p. [In Finnish.]

Mitina, E. G. \& Kuznetsova, O. M. 2006: (On the fauna of insect pests on trees and shrubs in the city of Murmansk.) - Scientific Transactions of Murmansk State Pedagogical University, Biological Sciences 2: 49-56. [In Russian.]

Mozolevskaya, E. G. 1999: (Specificity of structure and population dynamics of dendrophagous insect fauna and its role in forests of the North.) - In: Dolgin, M. M. (ed.), (Biodiversity of terrestrial and soil invertebrates in the North.) International Conference, September 15-17, 1999. Abstracts: 147-148. Syktyvkar State University, Syktyvkar. [In Russian.]

Nordström, F., Opheim, M. \& Valle, K. J. 1955: De fennoskandiska dagfjärilarnas utbredning. Lepidoptera Diurnia (Rhopalocera \& Hesperioidea). — Lunds Universitets Årsskrift 51: 1-177.

Nordström, F., Opheim, M. \& Sotavalta, O. 1961: De fennoskandiska svärmarnas och spinnarnas utbredning (Sphinges, Bombycomorpha etc.). - Lunds Universitets. Årsskrift 57: 1-92, maps 1-181.

Povolný, D. 2002: Iconographia tribus Gnorimoschemini (Lepidoptera, Gelechiidae) regionis Palaearcticae. Franisek Slamka, Bratislava. 110 p.

Shutova, E. V. 2004: (Additions and changes to the checklist of Lepidoptera of the Kandalaksha State Nature Reserve.) - In: Kljuikov, E. Yu. (ed.), Rational exploitation of the coastal zone of the Northern Seas. $6^{\text {th }}$ and $7^{\text {th }}$ International Workshops. Materials of the re- ports [sic!], pt. 1: 144-160. Russian State Hydrometeorological University, St. Petersburg. [In Russian.]

Shutova, E. V. 2008: (Second addition to the check-list of Lepidoptera of the Kandalaksha Reserve.) - In: Melnikov, M. V. (ed.), (Ecologo-faunistic studies in Central Black Earth zone and neighbouring areas.) Materials of $3^{\text {rd }}$ regional conference, Lipetsk, 19-21 February 2008: 159-165. Lipetsk State Pedagogical University, Lipetsk. [In Russian.]

Shutova, E. V., Antonova, E. M., Sviridov, A. V. \& Kutenkova, N. N. 1999: (Lepidoptera of the Kandalaksha reserve.) - Commission of the Russian Academy of Sciences on Nature Reserves, Moscow, 48 p. (Flora and Fauna of Nature Reserves, 80). [In Russian.]

Sinev, S. Yu. (ed.) 2008: Catalogue of the Lepidoptera of Russia. - KMK Scientific Press, St. Petersburg \& Moscow. 424 p. [In Russian.]

Sviridov, A. V. 1970: (Moths and butterflies (Lepidoptera, Macrolepidoptera) in surroundings of Belomorskaya biological station of Moscow State University, and their distribution across habitats.) — Entomologicheskoe Obozrenie 49: 563-572. [In Russian.]

Sviridov, A. V. \& Shutova, E. V. 2002: Noctuid moths (Lepidoptera) new for different areas of the Russian Federation, 1. Murmansk region. - Russian Entomological Journal 11: 447. [In Russian.]

Sviridov, A. V., Trofimova, T. A., Uskov, M. V., Mukhanov, A. V., Lobkova, L. E., Shchurov, V. I., Shutova, E. V., Kuznetsov, I. V., Lovtsova, Yu. A., Korzhov, P. N., Okulov, V. S. \& Klepikov, M. A. 2006: Noctuid moths (Lepidoptera) new for different regions of Russia. 2. — Eversmannia 7/8: 46-68. [In Russian.]

Sviridov, A. V., Uskov, M. V., Lobkova, L. E., Reshetnikov, S. P., Proklov, V. V., Tatarenko, D. E., Shutova, E. V., Mosyagina, A. R., Mukhanov, A. V., Polumordvinov, O. A., Shibaev, S. V., Kuznetsov, I. V., Blinushov, A. E., Burtnev, R. N., Ishin, R. N., Bolshakov, L. V., Ryabov, S. A. \& Okulov, V. S. 2009: Noctuid moths (Lepidoptera) new for different regions of the Russia. 3. - Eversmannia 17/18: 81-99. [In Russian.]

Tammaru, T., Virtanen, T., Ruohomäki, K. \& Kaila, L. 1995: Eupithecia veratraria Herrich-Schäffer, 1850 new to Scandinavia, with the redescription of $E$. veratraria ssp. arctica Viidalepp, 1974 (Lepidoptera, Geometridae). — Nota Lepidopterologica 18: 297-303.

Tengström, J. M. J. af. 1869: Catalogus Lepidopterorum faunae Fennicae praecursorius. - Notiser ur Sällskapets pro Fauna och Flora Fennica Forhandlingar 10: 287-371.

Tuzov, V. K., Bogdanov, P. V., Devyatkin, A. L., Kaabak, L. V., Korolev, V. A., Murzin, V. S., Samodurov, G. D. \& Tarasov, E. A. 1997: Guide to the butterflies of Russia and adjacent territories. Vol. 1. Hesperiidae, Papilionidae, Pieridae, Satyridae. - Pensoft Publ., Sofia $\&$ Moscow. 480 p.

Tuzov, V. K., Bogdanov, P. V., Churkin, S. V., Dantchenko, A. V., Devyatkin, A. L., Murzin, V. S., Samodurov, G. D. \& Zhdanko, A. B. 1997: Guide to the butterflies of Russia and adjacent territories (Lepidoptera, Rhopalocera). Vol. 2. Libytheidae, Danaidae, Nymphalidae, 
Riodinidae, Lycaenidae. — Pensoft Publ., Sofia \& Moscow. 580 p.

Valle, K. J. 1933: Die Lepidopterenfauna des Petsamogebietes under faunistisch-zoogeographischer Berücksichtigung der Fauna ganz N-Fennoscandias. - Annales Zoologici Societatis Zoologicae Botanicae Fennicae "Vanamo" 1: 1-262.

Zagulajev, A. K. 1964: (Family Tineidae. Subfamily Nemapogoninae. Fauna of USSR. Lepidoptera. Vol. 4, pt. 2.) - Nauka, Leningrad. 424 p. [In Russian.]

Zagulajev, A. K. 1981: (Fam. Ethmiidae - ethmiid moths.) — In: Falkovich, M. I. \& Medvedev, G. S. (eds.), Keys to the insects of the European part of the USSR. Vol. 4. Lepidoptera, pt. 2: 638-651. Nauka, Leningrad. [In Russian.]

Zvereva, E. L. \& Kozlov, M. V. 2000: Effect of air pollution on natural enemies of the leaf beetle, Melasoma lapponica. - Journal of Applied Ecology 37: 298308.

Zvereva, E. L. \& Kozlov, M. V. 2006: Top-down effects on population dynamics of Eriocrania miners (Lepidoptera) under pollution impact: does enemy-free space exist? - Oikos 115: 413-426. 